김중곤 ${ }^{1,2}$, 김태현 ${ }^{2,3,4} *$

\title{
Isolation and Characterization of Xylanolytic Bacteria from Horse Manure
}

\author{
Jung Kon Kim ${ }^{1,2}$ and Tae Hyun Kim ${ }^{2,3,4} *$ \\ 접수: 2011년 7월 22일 / 게재승인: 2011년 9월 5일 \\ (C) 2011 The Korean Society for Biotechnology and Bioengineering
}

\begin{abstract}
Twenty six microorganisms were isolated from soil and horse manure samples from in Iowa, U.S. Microorganisms were cultivated and screened by using plate count agar (PCA) at $35^{\circ} \mathrm{C}$ containing $1 \%(\mathrm{w} / \mathrm{v})$ oat spelt xylan instead of glucose. The xylanase activities of bacterial strains were analyzed by measuring the concentration of reducing sugar by DNS method. All isolated strains were characterized as the rod form and gram positive strains. Among the isolated strains, the HM6 strains gave the highest xylanase activity. This strain was identified as Bacillus pumilus HM6 by 16S rDNA sequence, morphological and biochemical analysis. Optimal culture temperature and initial medium $\mathrm{pH}$ for B. pumilus HM6 were $30-35^{\circ} \mathrm{C}$ and $\mathrm{pH} 6-7$, respectively. The maximum xylanase activity of $6879 \mathrm{IU} / \mathrm{mL}$ was obtained after growth of HM6 with $1 \%(\mathrm{w} / \mathrm{v})$ oat spelt xylan at $35^{\circ} \mathrm{C}$ for 6 days. Studies on enzymatic properties showed that the optimum conditions for the highest xylanase activity were $60^{\circ} \mathrm{C}$ and

\footnotetext{
${ }^{1}$ 농촌진흥청 국립식량과학원 바이오에너지 작물센터

${ }^{1}$ Bioenergy Crop Research Center, National Institute of Crop Science, Rural Development Administration, 293-5, Cheongcheon, Cheonggye, Muan, Jeonnam 534-833, Korea

${ }^{2}$ 아이오와 주립대학교 농업바이오시스템공학과

${ }^{2}$ Department of Agricultural and Biosystems Engineering, Iowa State University, Ames, Iowa, 50011-3310, USA

${ }^{3}$ 아아오와 주립대학교 자원생태경영학과

${ }^{3}$ Department of Natural Resource Ecology and Management, Iowa State University, Ames, IA 50011, United States

${ }^{4}$ 아아오와 주립대학교 작물이용연구센터

${ }^{4}$ Center for Crops Utilization Research. Iowa State University, Ames, IA 50011, United States

Tel: +1-515-294-7136, Fax: +1-515-294-4250

e-mail: thkim@iastate.edu
}

$\mathrm{pH}$ 8.0. In addition, xylanase activity was stable over 2 hours at $50^{\circ} \mathrm{C}$, whereas activity decreased after $30 \mathrm{~min}$ at $70^{\circ} \mathrm{C}$.

Keywords: Bacillus pumilus, xylanase, lignocellulosic biomass, hemicellulose

\section{1. 서론}

식물세포벽의 hemicellulose를 구성하는 주요 구성성분으로 알려진 xylan은 주로 4-O-methyl-D-glucuronic acid 및 Larabinofuranose 또는 acetic acid에 의해 치환된 형태로 존재 한다. 이러한 xylan을 분해하기 위해서는 endo- $\beta-1,4$-xylanase, $\beta$-xylosidase, $\alpha$-D-glucuronidase, $\alpha$-L-arabinofuranosidase, ferulic acid esterase, 그리고 acetyl-xylan esterase 등의 여러 가지 hemicellulase가 필요하며 그 가운데 endo- $\beta-1,4$-xylanase 는 xylan의 분해에 있어서 가장 중요한 효소이다 [1-3]. 또한 xylanase의 활용분야로서 가축사료의 효율개선, 제지의 표백 공정, 과일음료의 청징, 농업 부산물 이용성 증대 등을 위해 이용되고 있으며 $[4,5]$, 최근에 섬유소계바이오매스를 이용한 바이오에너지에 대한 관심이 전세계적으로 증가됨에 따라 비 식량작물인 섬유소계바이오매스의 cellulose와 hemicellulose 의 효율적인 당화를 위해 cellulase와 더불어 xylanse에 대한 연구가 활발해지고 있다 [6,7]. 특히 섬유소계바이오매스내 의 D-xylose를 발효하여 에탄올을 생산하는 연구가 [8] 진행 됨으로써 D-xylose의 이용가능성이 높아지게 되었고, 그로 인해 xylan의 가수분해에 관여하는 xylanase의 관심도 높아 지게 되었다.

지금까지 세균 및 곰팡이를 포함한 다양한 종류의 xylanase 생산 미생물들이 토양, 퇴비 및 초식동물과 무척추동물의 장과 같은 여러 환경으로부터 분리되었다. 곰팡이 중에서는 
주로 Aspergillus 속 [9] 균주와 Trichoderma 속 [10] 균주가 많이 보고되었으며, 방선균 중에서는 Streptomyces 속 균주, 그리고 일반세균에서는 Bacillus [11]와 Clostridium 속 [12] 균주에 의해 생산되는 xylanase의 다양한 특성에 대한 연 구가 보고되었다. 특히 세균인 Bacillus속에 의해 생산되는 xylanase의 경우 곰팡이에 비해 배양시간이 짧고 많은 효소 를 단 시간 내에 얻을 수 있으며 중성, 알칼리성 등의 환경적 조건에 적합한 효소를 쉽게 생산할 수 있다는 장점을 가지 고 있다 [13].

본 연구에서는 미국 아이오와 지역의 토양 및 말똥으로부 터 xylan 분해력이 우수한 세균을 분리하여 이를 동정하고 분리한 균주의 생장 특성 및 분리 균주가 분비하는 효소의 특성에 대해 조사하였다.

\section{2. 재료 및 방법}

\subsection{Xylanase 생산균주의 분리 및 동정}

Xylanase 생산균주의 분리를 위해 아이오와 지역에서 수집 한 토양시료 및 말똥시료 $1 \mathrm{~g}$ 을 $0.85 \% \mathrm{NaCl}$ 용액에 현탁 시켜 연속 희석한 후 적정 농도의 희석액 $100 \mathrm{~mL}$ 를 취하여 glucose 대신 $1 \%$ 의 oat spelt xylan이 첨가된 분리용 배지인 PCA (Plate Count Agar) 평판배지 (yeast extract, $2.5 \mathrm{~g}$; peptone, $5 \mathrm{~g}$; oat spelt xylan, $10 \mathrm{~g}$, water, $1.0 \mathrm{~L}$ )에 도말한 후 $35^{\circ} \mathrm{C}$ 에서 24-48시간 동안 배양하였다. 이후 평판배지상 에 나타난 성상이 다른 각각의 콜로니를 순수 분리하였으며, xylanase 생산균주들을 선별하기 위해 평판배지상에 나타난 xylan 분해환을 관찰하여 그 크기가 큰 균주들을 선별하였 다. 분리균주의 동정은 형태적, 생화학적 특성 및 $16 \mathrm{~s} \mathrm{rDNA}$ 유전자 염기서열을 조사하여 동정하였다. 형태학적 특성 조사를 위해 그람 염색을 실시하였으며, API $50 \mathrm{CHB}$ kit (bioMerieux Vitek, France)를 이용하여 $35^{\circ} \mathrm{C}$ 에서 48시간 배양한 후 생화학적 특성을 확인하였다.

\section{2. 배양온도 및 $\mathrm{pH}$ 에 따른 생장 영향}

배양온도 및 $\mathrm{pH}$ 에 따른 생장 영향을 알아보기 위해 $\mathrm{PCA}$ 배지에서 1 일간 $35^{\circ} \mathrm{C}$ 에서 전 배양된 분리균주의 배양액을 접종하여 배양하였다. 배양온도에 따른 생장 영향을 조사하 기 위해 배양온도를 $30-50^{\circ} \mathrm{C}$ 까지 $5^{\circ} \mathrm{C}$ 간격으로 조절하여 2 일간 진탕배양하는 동안 배양 초기에는 2 시간, 12 시간 이후 에는 6 시간, 마지막으로 36 시간 이후에는 12 시간마다 배양 액을 취하여 $600 \mathrm{~nm}$ 에서 측정한 흡광도를 이용하여 배양 온도에 따른 분리균주의 생장 영향을 조사하였다. 또한 $\mathrm{pH}$ 에 대한 생장 영향을 조사하기 위해 배양배지의 초기 $\mathrm{pH}$ 를 2-12까지 조절한 뒤 전 배양된 분리균주의 배양액을 접종 하여 2 일간 진탕배양하는 동안 3 시간마다 배양액을 취하여 $600 \mathrm{~nm}$ 에서 측정한 흡광도를 이용하여 배양배지의 초기 $\mathrm{pH}$ 에 따른 분리균주의 생장 영향을 조사하였다.

\subsection{Xylanase 활성 측정}

분리된 균주에서 생산된 xylanase의 활성을 측정하기 위해 glucose 대신 1\% oat spelt xylan이 포함된 PCA 액체배지 에서 배양된 분리균주의 상등액을 조효소로 사용하였으며, xylanase의 활성도는 3,5-dinitrosalicylic acid (DNS) 방법 [14] 을 사용하여 oat spelt xylan으로부터 유리된 xylose 함량을 측정하여 분석하였다. 본 연구에 사용된 효소활성측정을 위 한 표준 반응용액은 조효소액 $500 \mu \mathrm{L}$ 와 $1 \%$ oat spelt xylan 용액 $500 \mu \mathrm{L}$ 를 완전 혼합하여 $50^{\circ} \mathrm{C}$ 에서 30 분간 반응시킨 후, $\mathrm{DNS}$ 용액 $1 \mathrm{~mL}$ 을 첨가한 뒤 끓는 물속에 시험관을 담궈 중 탕시키면서 5 분간 발색시킨 후 증류수 $10 \mathrm{~mL}$ 를 첨가하고 $540 \mathrm{~nm}$ 에서 흡광도를 측정하였다. 대조군은 조효소액 $500 \mu \mathrm{L}$ 와 증류수 $500 \mu \mathrm{L}$ 를 혼합하여 시료와 동일하게 수행하였다. 효소활성 1 international unit (IU)는 1 분간 $1 \mu \mathrm{mol}$ 의 xylose 에 상응하는 환원당을 생성하는 효소의 양으로 정의하였다.

\subsection{Xylanase 활성에 대한 온도 및 $\mathrm{pH}$ 의 영향}

Xylanase의 효소 활성에 미치는 온도 및 $\mathrm{pH}$ 의 영향을 알아 보기 위해 HM6 균주에서 생산된 조효소 액을 반응에 사용 하였다. 효소 반응의 최적 온도를 조사하기 위해, BrittonRobinson 완충용액 (pH 7.0)에서 $1 \%$ oat spelt xylan을 기질 로 사용하여 $20-80^{\circ} \mathrm{C}$ 까지 $10^{\circ} \mathrm{C}$ 간격으로 조절하여 반응시킨 후 상기 서술한 효소활성 측정방법을 통하여 효소 활성을 비 교하였다. 효소의 열 안정성은 Britton-Robinson 완충용액 $(\mathrm{pH} 7.0)$ 에 조효소를 첨가하여 $40-70^{\circ} \mathrm{C}$ 까지 $10^{\circ} \mathrm{C}$ 간격으로 조절된 각 온도에서 120 분간 처리한 후에 효소의 잔존 활성을 측정하였다. 효소의 최적 $\mathrm{pH}$ 를 조사하기 위해서는, 조효소 액을 $\mathrm{pH}$ 가 2-12까지 1.0 간격으로 조절된 Britton-Robinson 완충용액에 넣고 $50^{\circ} \mathrm{C}$ 에서 30 분간 반응시킨뒤 활성을 비교 하였다.

\section{3. 결과 및 고찰}

\section{1. 균주의 분리 및 동정}

아이오와 지역에서 수집한 토양시료 및 말똥시료를 $1 \%$ oat spelt xylan이 첨가된 $\mathrm{PCA}$ 평판배지에 도말 후 $35^{\circ} \mathrm{C}$ 에서 $1-2$ 일간 배양하여 평판배지상에 나타난 성상이 각각의 콜로 니를 순수 분리하였다. 이 후 순수 분리된 균주들 가운데 xylanase 생산균주들을 선별하기 위해 평판배지상에 나타난 xylan 분해환을 관찰하여 Table 1에 나타낸 바와 같이 26주 를 1 차 선별하였으며, 이들 중 그 크기가 큰 균주 5 주를 선별 하였고 (Fig. 1), 효소활성 측정을 통하여 최종적으로 1주를 선별하였다. 최종 선별된 분리균은 HM6로 명명하였고, 말똥으로부터 분리되었으며, 그람 염색과 morphology 관찰 결과 그람 양성의 간균으로 밝혀졌다. 또한 HM6의 생화학적 특성을 API 50 CHB kit를 이용하여 조사한 결과 glycerol, L-arabinose, D-ribose, D-xylose, D-galactose, G-glucose, D-fructose, D-mannose, L-rhamnose, D-mannitol, methyl- $\alpha$ D-mannopyranoside, N-acetylglucosamine, amygdalin, arbutin, esculin ferric citrate, salicin, D-cellobiose, D-lactose, D-melibiose, D-saccharose, D-trehalose, lnulin, D-raffinose, xylitol, gentiobiose, D-tagatose, D-arabitol은 이용하였으 
나, 다른 탄수화물은 이용하지 못하는 것으로 확인되었다 (Table 2). 상기 형태적 및 생화학적 특성의 결과를 바탕으로 분리균주는 Bacillus 속 균주 중 B. circulans, B. pumilus 및 B. megaterium 과 유사성을 보이는 것으로 나타났으며, $16 \mathrm{~s}$ $\mathrm{rDNA}$ 유전자의 염기서열을 분석한 후 $\mathrm{NCBI}$ 의 BLAST search program을 이용하여 상동성을 비교한 결과, $99 \%$ 의 신뢰도로 B. pumilus 에 속하는 것으로 나타났으므로, 선발한 균주를 B. pumilus HM6로 명명하였다 (Fig. 2).

Table 1. The detection results of xylanase activities from isolated strains in screening media

\begin{tabular}{lccccc}
\hline \multicolumn{1}{c}{ Strains } & Source & $\begin{array}{c}\text { Xylanase } \\
\text { activity }\end{array}$ & Strains & Source & $\begin{array}{c}\text { Xylanase } \\
\text { activity }\end{array}$ \\
\hline S-JK1 & Soil & + & HM7 & Horse manure & + \\
S-JK2 & Soil & + & HM8 & Horse manure & +++ \\
S-JK3-1 & Soil & +++ & HS2 & Horse barn soil & + \\
S-JK4 & Soil & ++ & HS3 & Horse barn soil & + \\
S-JK5 & Soil & ++ & HS4 & Horse barn soil & +++ \\
S-JK6 & Soil & +++ & HS5 & Horse barn soil & + \\
S-JK7 & Soil & ++ & HS6 & Horse barn soil & +++ \\
S-JK8 & Soil & ++ & HS7 & Horse barn soil & + \\
S-JK9 & Soil & +++ & HS8 & Horse barn soil & +++ \\
HM1 & Horse manure & + & HS9 & Horse barn soil & + \\
HM2 & Horse manure & + & HS10 & Horse barn soil & + \\
HM5 & Horse manure & + & HS12 & Horse barn soil & +++ \\
HM6 & Horse manure & +++ & & & \\
\hline
\end{tabular}

+++ represents excellent clear zone formation on the screening medium; ++ good; + fair; - negative.

Table 2. Biochemical characteristics of B. pumilus HM6 isolated from horse manure

\begin{tabular}{lclc}
\hline \multicolumn{1}{c}{ Characteristics } & Result & \multicolumn{1}{c}{ Characteristics } & Result \\
\hline Control & - & Esculin ferric citrate & + \\
Glycerol & + & Salicin & + \\
Erythritol & - & D-cellobiose & + \\
D-arabinose & - & D-maltose & - \\
L-arabinose & + & D-lactose (bovine origin) & W \\
D-ribose & + & D-melibiose & W \\
D-xylose & + & D-saccharose (sucrose) & + \\
L-xylose & - & D-trehalose & + \\
D-adonitol & - & Inulin & W \\
Methyl- $\beta$ D-xylopyranoside & - & D-Melezitose & - \\
D-galactose & + & D-Raffinose & W \\
D-glucose & + & Amidon (starch) & - \\
D-fructose & + & Glycogen & - \\
D-mannose & + & Xylitol & W \\
L-sorbose & - & Gentiobiose & W \\
L-rhamnose & W & D-Turanose & - \\
Dulcitol & - & D-lyxose & - \\
Inositol & - & D-Tagatose & + \\
D-mannitol & + & D-Fucose & - \\
D-sorbitol & - & L-Fucose & - \\
Methyl- $\alpha$ D-mannopyranoside & W & D-arabitol & W \\
Methyl- $\alpha$ D-glucopyranoside & - & L-arabitol & - \\
N-acetylglucosamine & W & Potassium glucoNaTe & - \\
Amygdalin & W & Potassium 2-ketogluconate & - \\
Arbutin & + & Potassium 5-ketogluconate & - \\
\hline & & &
\end{tabular}

+ represents good utilization; $\mathrm{W}$ weak; - negative.

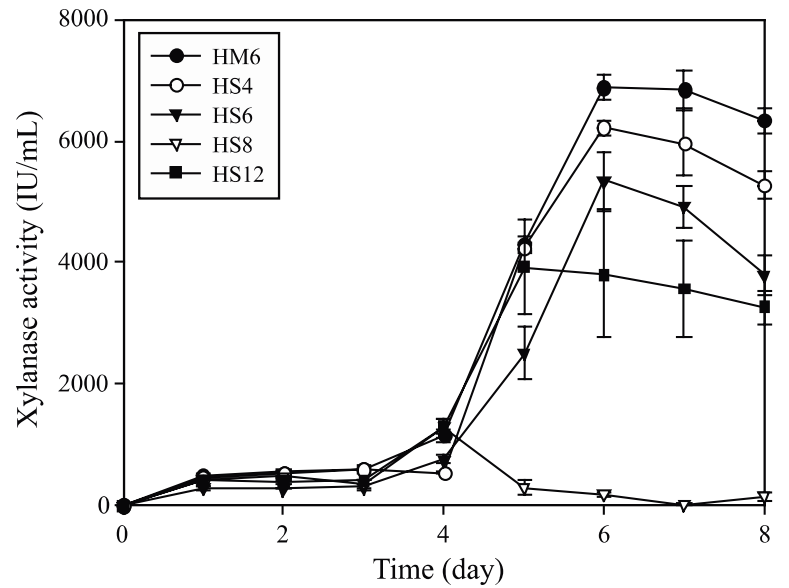

Fig. 1. Xylanase production of B. pumilus HM6. Xylanase activity was determined with the culture supernatants.

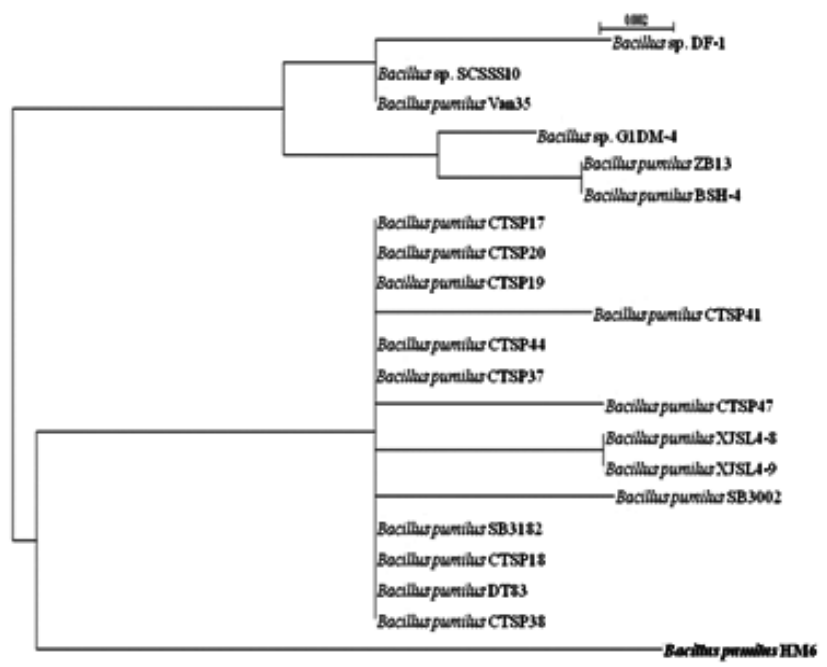

Fig. 2. Phylogenetic relationship of isolated strain HM6 with other Bacillus species based on partial 16s rDNA gene sequences. The dendrogram shows the results from analysis using CLUSTAL-X and TREE-VIEW.

\section{2. 배양온도 및 $\mathbf{p H}$ 에 따른 생장 영향}

Fig. 3은 배양온도에 따른 분리균주 B. pumilus HM6의 생장 영향을 나타낸 그림이다. 분리균주 HM6 균주의 최적 생장 온도는 $30-35^{\circ} \mathrm{C}$ 로 나타났으며, $40-50^{\circ} \mathrm{C}$ 까지 성장은 가능하 지만 $50^{\circ} \mathrm{C}$ 의 온도조건에서 생장이 현저히 떨어지는 것을 확 인할 수 있었고, $55^{\circ} \mathrm{C}$ 이상에서는 생장하지 못하였다. 이것 은 일반적인 중온성 B. pumilus 의 경우 $50^{\circ} \mathrm{C}$ 를 초과하는 온도 에서는 성장할 수 없다고 보고한 Droffner와 Yamamoto의 결과와 일치하였다 [15]. $\mathrm{pH}$ 에 대한 생장 영향의 경우 본 연구에서 분리된 $\mathrm{HM} 6$ 는 $\mathrm{pH}$ 2-3의 산성영역에서는 성장하 지 못하였지만, 염기성 영역인 $\mathrm{pH} 12$ 까지 생장이 가능하였 고, 가장 생장상태가 우수한 $\mathrm{pH} \mathrm{6-7이} \mathrm{최적} \mathrm{생장} \mathrm{pH}$ 로 판단 된다 (Fig. 4). Hill 등이 새우에서 분리한 B. pumilus의 최적 생장 $\mathrm{pH}$ 는 6-9였으며, $\mathrm{pH} 11$ 을 초과하는 범위에서는 성장 할 수 없었다 [16]. 따라서 본 분리균주 HM6 균주가 알칼리 성에 더 강한 균주로 사료된다. 


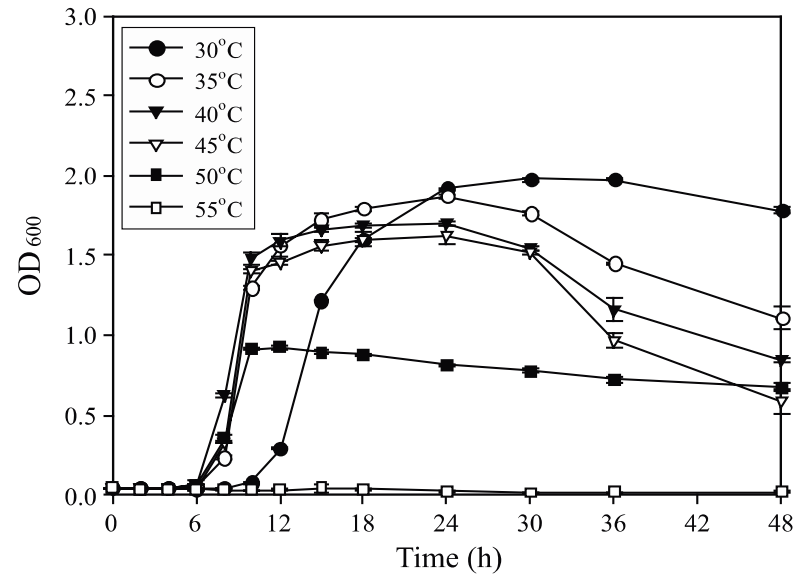

Fig. 3. Effects of temperature on the growth of B. pumilus HM6 in the PCA broth.

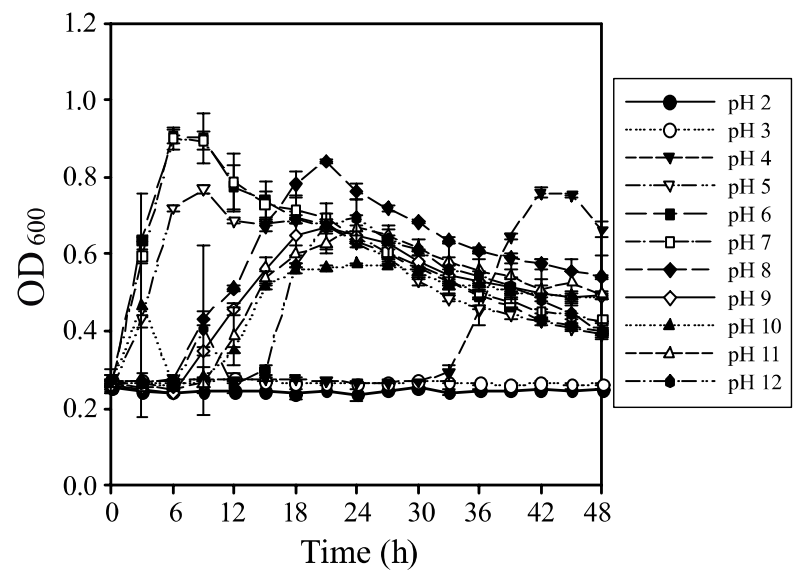

Fig. 4. Effects of initial pH on the growth of B. pumilus HM6 in the PCA broth.

\section{3.배양 시간에 따른 xylanase 활성특성}

B. pumilus HM6가 세포외로 분비 생산하는 xylanase의 반응 특성을 조사하기 위해 배양액을 원심분리하여 얻은 배양상 등액을 조효소액으로 사용하였다. Table 3 에 보인 바와 같이 일반적으로 세균으로부터 xylanase를 생산하는 데 소요되는 배양시간은 1-2일이며, 활성도 또한 $1000 \mathrm{IU} / \mathrm{mL}$ 전후이다.
이에 반해 곰팡이나 버섯으로부터 생산된 xylanase는 세균 에 비해 활성도가 매우 높지만 장시간의 배양시간을 요구한 다. 그러나 본 연구에서 선별된 분리균주들의 경우 초기 3일 간의 xylanase의 활성도는 약 260-640 IU/mL으로 일반적인 세균유래 xylanase와 비슷한 활성을 나타내었지만 4일 이후 활성도가 급격히 증가하였으며, 특히 HM6의 경우 최고 약 $7000 \mathrm{IU} / \mathrm{mL}$ 까지 활성도가 증가하였다 (Fig. 1). 따라서 초기 xylanase의 활성은 일반적인 세균유래 xylanase와 비슷한 활성을 나타내었지만 배양시간이 길어질수록 효소활성도가 훨씬 증가하여 곰팡이나 버섯으로부터 생산된 xylanase의 활성도와 비슷한 활성도를 나타내었다 (Table 3) [17-25]. 이것은 배양시간이 길어짐에 따라 세포외로 분비된 xylanase 의 양이 많아짐과 동시에 길어진 배양시간 동안 사멸기에 접어든 세포가 용해되면서 세포 내에 존재하는 영양성분이 배양액에 혼합되어 xylanase의 활성에 알지 못하는 영향을 미친 것으로 사료된다. 또한 본 연구에서 분리된 HM6는 곰팡이나 버섯으로부터 생산된 xylanase와 활성이 비슷한 정도의 활성도를 보이면서 배양시간이 더 짧다는 것은 균주 의 이용가능성 측면에서 상당한 이점으로 판단된다.

\subsection{Xylanase 활성에 미치는 온도 및 $\mathrm{pH}$ 의 영향}

Fig. 5와 6은 각각 xylanase의 반응온도와 $\mathrm{pH}$ 를 달리하여 xylanase 활성을 측정함으로써 반응온도와 $\mathrm{pH}$ 가 xylanase 활성에 미치는 영향을 조사하였다. 그 결과 반응온도가 효소활성에 미치는 영향의 경우 Fig. 5(a)에서 보인 바와 같이 $60^{\circ} \mathrm{C}$ 에서 가장 높은 활성을 나타내었으며, $50^{\circ} \mathrm{C}$ 의 경우 상대활성도가 약 $99 \%$ 로 최고활성을 보인 $60^{\circ} \mathrm{C}$ 와 유사한 결과를 얻었다. 또한 활성 측정범위인 $20-80{ }^{\circ} \mathrm{C}$ 까지 $65 \%$ 이상의 비교적 높은 효소활성을 보였으며, 특히 $70^{\circ} \mathrm{C}$ 에서도 약 $89 \%$ 이상의 활성도를 보였다. 열에 대한 안정성의 경우 Fig. $5(\mathrm{~b})$ 에 나타낸 바와 같이 $40^{\circ} \mathrm{C}$ 와 $50^{\circ} \mathrm{C}$ 의 경우 90 분 동 안 활성도의 $80 \%$ 이상을 유지하였으며, 최종 시험시간인 120 분에서도 $78 \%$ 의 활성도를 유지하였다. 반면에 $60^{\circ} \mathrm{C}$ 의 경우 30 분 후 활성도가 $45 \%$ 로 급격히 떨어졌으며, 60 분 이후에는 $20 \%$ 이하로 효소활성이 떨어졌고, $70^{\circ} \mathrm{C}$ 에서는 30 분 이후부터 효소활성이 $20 \%$ 이하로 떨어졌다. 따라서 열 안정성을 고려할 때 분리균주의 최적반응온도는 $50^{\circ} \mathrm{C}$

Table 3. Comparison of xylanase productivity in some of the highest producing strains

\begin{tabular}{|c|c|c|c|c|c|}
\hline Organism & Growth substrate & $\begin{array}{c}\text { Xylanase yield } \\
(\mathrm{IU} / \mathrm{mL})\end{array}$ & $\begin{array}{l}\text { Cultivation } \\
\text { time (h) }\end{array}$ & $\begin{array}{c}\text { Productivity } \\
(\mathrm{IU} / \mathrm{mL} / \mathrm{h})\end{array}$ & Reference \\
\hline Bacillus pumilus & Oat spelt xylan & 6879 & 144 & 46.38 & This paper \\
\hline Bacillus sp. & Hydrolysed xylan & 1000 & 15 & 66.67 & {$[17]$} \\
\hline Thermomyces lanuginosus & Xylan & 1433 & 38 & 37.71 & {$[18]$} \\
\hline Thermomyces lanuginosus & Corn cobs & 7575 & 216 & 35.07 & [19] \\
\hline Schizophyllum commune & Microcrystalline cellulose & 5740 & 264 & 21.74 & {$[20]$} \\
\hline Trichoderma reesei & Xylan & 970 & 50 & 19.4 & {$[21]$} \\
\hline Streptomyces lividans recomb. & Xylan & 784 & 48 & 16.33 & {$[22]$} \\
\hline Aureobasidium pullulans mutant & Xylan & 633 & 70 & 9.04 & [23] \\
\hline Bacillus circulans & Deacetylated xylan & 400 & 48 & 8.33 & {$[24]$} \\
\hline Yeast sp. & Xylan & 570 & 70 & 8.14 & [25] \\
\hline
\end{tabular}


(a)

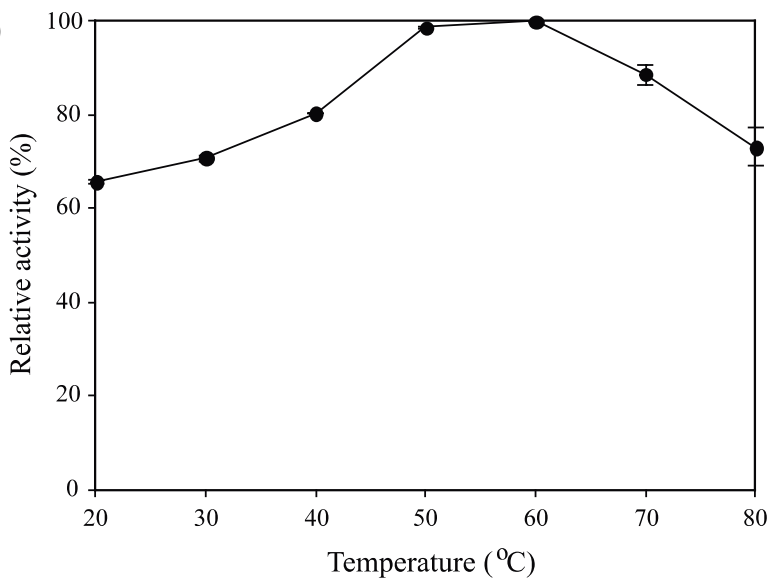

(b)

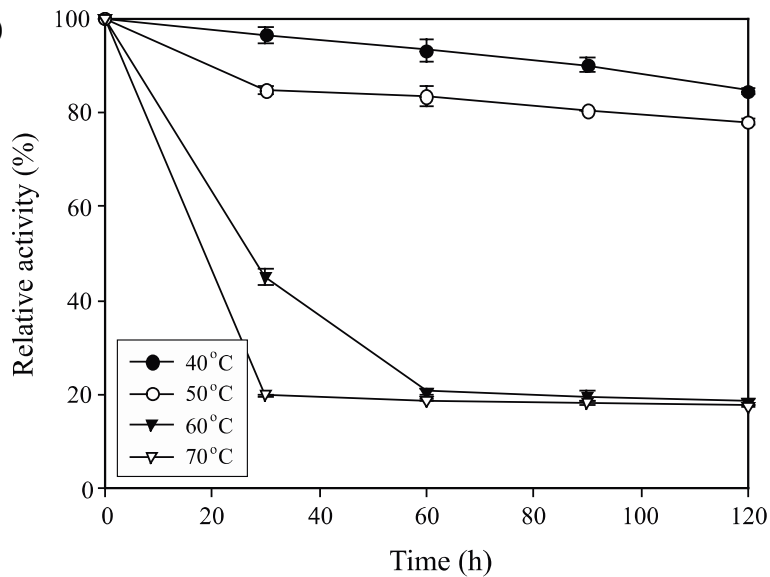

Fig. 5. Effect of temperature (a) on the xylanase activity and temperature stability (b) of xylanase from B. pumilus HM6.

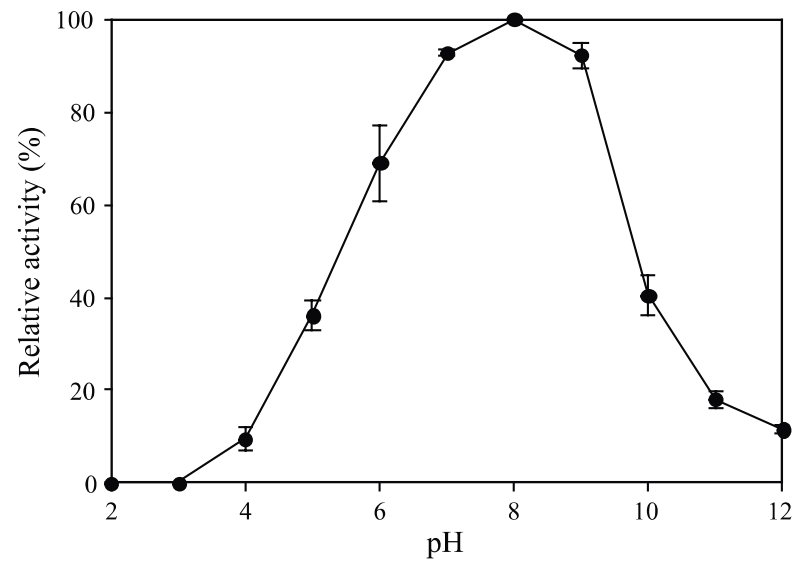

Fig. 6. Effect of $\mathrm{pH}$ on the activity of xylanase from B. pumilus HM6.

로 판단된다. Fig. 6 은 $\mathrm{pH}$ 가 효소활성에 미치는 영향을 나 타낸 것이다. 가장 높은 활성은 $\mathrm{pH}$ 8에서 보였으며, 7-9사 이의 $\mathrm{pH}$ 영역에서 비교적 높은 효소활성도를 나타내었다. 그러나 $\mathrm{pH}$ 5이하와 $\mathrm{pH} 10$ 이상에서는 효소활성도가 급격 히 저하되어 중성영역과 약 알칼리 영역의 $\mathrm{pH}$ 에서 효소활 성이 높게 유지됨을 알 수 있었다. 따라서 본 연구에서 분 리된 B. pumilus HM6로부터 생산된 xylanase의 최적 반응
온도 및 $\mathrm{pH}$ 는 $50^{\circ} \mathrm{C}$ 와 $\mathrm{pH} 8$ 임을 알 수 있었다. 윤 등 [26] 이 분리한 Bacillus sp. AMX-4와 이 등 [2]이 분리한 Bacillus sp. HY-20로부터 생산된 xylanase의 경우 최적 반응 온도 및 $\mathrm{pH}$ 는 각각 $50^{\circ} \mathrm{C}$ 와 $\mathrm{pH} 6.0$ 그리고 $55^{\circ} \mathrm{C}$ 와 $\mathrm{pH} 6.5$ 로 보고된 바 있다. 그러므로 본 연구에서 분리된 HM6의 xylanase는 이들 균이 생산하는 효소와 비슷한 중온성 xylanase인 반면 약칼리성에서 반응활성이 더 높은 것을 알 수 있었다.

\section{4. 결론}

미국 아이오와주의 토양 및 말똥으로부터 26 개의 균주가 glucose 대신에 $1 \%(\mathrm{w} / \mathrm{v})$ oat spelt xylan이 포함된 PCA 배지를 이용하여 $35^{\circ} \mathrm{C}$ 에서 분리되었다. 분리된 균주의 xylanase 활성은 $1 \%(\mathrm{w} / \mathrm{v})$ oat spelt xylan을 기질로 이용하여 DNS법 에 의한 환원당을 측정함으로써 분석하였다. 분리된 균주들 은 모두 그람 양성에 간균이었으며, 이 가운데 말똥으로부터 분리된 HM6 균주가 가장 높은 xylanase활성을 보였다. 선별 된 HM6 균주의 형태적 및 생화학적특성 조사 결과와 $16 \mathrm{~s}$ rDNA 유전자의 염기서열을 바탕으로 분리균주는 Bacillus pumilus 에 속하는 것으로 조사되었고, 선발한 균주를 $B$. pumilus $\mathrm{HM} 6$ 로 동정하였다. B. pumilus HM6의 최적 성장 온도 및 초기 $\mathrm{pH}$ 는 각각 $30-35^{\circ} \mathrm{C}$ 와 $6.0-7.0$ 이었다. $\mathrm{HM} 6$ 의 가장 높은 xylanase 활성은 $1 \%(\mathrm{w} / \mathrm{v})$ oat spelt xylan이 포 함된 PCA 배지를 이용하여 $35^{\circ} \mathrm{C}$ 에서 6 일간 배양하였을 때 $6879 \mathrm{IU} / \mathrm{mL}$ 의 활성으로 가장 높았다. HM6로부터 생산된 xylanse의 온도 및 $\mathrm{pH}$ 에 대한 특성은 $60^{\circ} \mathrm{C}$ 의 온도와 $\mathrm{pH} 8.0$ 에서 가장 높은 활성을 보였고, 열에 대한 안정성은 $50^{\circ} \mathrm{C}$ 에 서 2 시간 동안 $80 \%$ 이상의 높은 활성을 유지하였으며, $60^{\circ} \mathrm{C}$ 이상에서는 30 분 후 활성이 급격히 떨어졌다.

감사

이 논문은 2008년 정부 (교육과학기술부)의 재원으로 한국 학술진흥재단의 지원을 받아 수행된 연구임 (이공분야: KRF2008-357-D00085).

\section{References}

1. Shallom, D. and Y. Shoham (2003) Microbial hemicellulases. Curr. Opin. Microbiol. 6: 219-228.

2. Lee, L. H., D. Y. Kim, M. K. Han, H. W. Oh, S. J. Ham, D. S. Park, K. S. Bae, D. E. Sok, D. H. Shin, K. H. Son, and H. Y. Park (2009) Characterization of an extracellular xylanase from Bacillus sp. HY-20, a bacterium in the gut of Apis mellifera. Kor. J. Microbiol. 45: 332-338.

3. Chatterjee, A., N. C. Das, S. Raha, R. Babbit, Q. Huang, D. Zaitlin, and I. B. Maiti (2010) Production of xylanase in transgenic tobacco for industrial use in bioenergy and biofuel applications. In Vitro Cell. Dev. Biol.-Plant 46: 198-209.

4. Lee, J. H. and S. H. Choi (2006) Xylanase production by Bacillus 
sp. A-6 isolated from rice bran. J. Microbiol. Biotechnol. 16: 1856-1861.

5. Kim, M. J., S. J. Lim, and D. K. Kang (2008) Isolation of a Bacillus licheniformis DK42 producing celluloseand xylanase, and properties of the enzymes. J. Anim. Sci. \& Technol. (Kor.) 50: 429-436.

6. Sticklen, M. B. (2008) Plant genetic engineering forbiofuel production: towards affordable cellulosic ethanol. Nat. Rev. 9: 433-443.

7. Hinchee, M., W. Rottmann, L. Mullinax, C. Zhang, S. Chang, M. Cunningham, L. Pearson, and N. Nehra (2009) Short-rotation woody crops for bioenergy and biofuels application. In Vitro Cell. Dev. Biol.-Plant 45: 619-629.

8. Du Preez, J. C., B. van Driessel, and B. A. Prior (1989) D-xylose fermentation by Candida shehatae and Pichia stipitisat low dissolved oxygen levels in fed-batch cultures. Biotechnol. Lett. 11: 131-136.

9. Siedenberg, D., S. R. Gerlach, K. Schugerl, M. L. F. Giuseppin, and J. Hunik (1998) Production of xylanase by Aspergillus awamori on synthetic medium in shake flask cultures. Process Biochem. 33: 429-433.

10. Tenkanen, H., J. Plus, and K. Poutanen (1992) Two major xylanases of Trichoderma reesei. Enzyme Microb. Technol. 14: 566-574.

11. Sunna, A. and G. Antranikian (1997) Xylanolytic enzymes from fungi and bacteria. Crit. Rev. Biotechnol. 17: 39-67.

12. Kosugi, A., K. Murashima, and R. H. Doi (2001) Characterization of xylanolytic enzymes in Clostridium cellulovorans: expression of xylanase activity dependent on growth substrates. $J$. Bacteriol. 183: 7037-7043.

13. Choi, J.-H. and D.-H. Bai (2010) Isolation and identification of alkalophilic microorganism producing xylanase. Food Engineering Progess 14: 263-270.

14. Miller, G. L. (1959) Use of dinitrosalicylic acid reagent for determination of reducing sugar. Anal. Chem. 31: 426-428.

15. Droffner, M. L. and N. Yamamoto (1985) Isolation of thermophilic mutants of Bacillus subtilis and Bacillus pumilusand transformation of the thermophilic trait to mesophilic strains. J. Gen. Microbiol. 131: 2789-2794.
16. Hill, J. E., J. C. F. Baiano, and A. C. Barnes (2009) Isolation of a novel strain of Bacillus pumilusfrom penaeid shrimp that is inhibitory against marine pathogens. J. Fish Dis. 32: 1007-1016.

17. Samain, E., Ph. Debeire, and J. P. Touzel (1997) High level production of a cellulose-free xylanase in glucose-limited fed batch cultures of a thermophilic Bacillus strain. J. Biotechnol. 58: 71-78.

18. Hoq, M. M., C. Hempel, and W. D. Deckwer (1994) Cellulasefree xylanase by Thermomyces lanuginosus RT9: Effect of agitation, aeration, and medium components on production. $J$. Biotenol. 37: 49-58.

19. Purkarthofer, H., M. Sinner, and W. Steiner (1993) Cellulase-free xylanase from Thermomyces lanuginosus: Optimization of production in submerged and solid-state culture. Enzyme Microb. Technol. 15: 677-682.

20. Haltrich, D., M. Preiss, and W. Steiner (1993) Optimization of a culture medium for enzyme increased xylanase production by a wild strain of Schizophyllum commune. Enzyme Microb. Technol. 15: 854-860.

21. Bailey, M. J., J. Buchert, and L. Viikari (1993) Effect of pH on production of xylanase by Trichoderma reesei on xylan- and cellulose-based media. Appl. Microbiol. Biotechnol. 40: 224-229.

22. Bertrand, J. L., R. Morosoli, F. Shareck, and D. Kluepfel (1989) Expression of the xylanase gene of Streptomyces lividans and production of the enzyme on natural substrates. Biotechnol. Bioeng. 33: 791-794.

23. Leathers, T. D. (1986) Color variants of Aureobasidium pullulans overproduce xylanase with extremely highspecific activity. Appl. Environ. Microbiol. 52: 1026-1030.

24. Rättö, M., K. Poutanen, and L. Viikari (1992) Production of xylanolytic enzymes by an alkalitolerant Bacillus circulars strain. Appl. Microbiol. Biotechnol. 37: 470-473.

25. Bastawde, K. B., U. S. Puntambekar, and D. V. Gokhale (1994) Optimization of cellulosefree xylanase production by a novel yeast strain. J. Ind. Microbiol. 13: 220-224.

26. Yoon, K.-H., S. J. Seol, H.-C. Cho, M.-S. Lee, J. H. Choi, and K. H. Cho (2002) Isolation and enzyme production of a xylanaseproducing strain, Bacillus sp. AMX-4. Kor. J. Microbiol. Biotechnol. 30: 123-128. 